\title{
Social Media Technology as an Implementation of Speech Strategy and Politeness Principle to Maintain Diversity in Multicultural Society
}

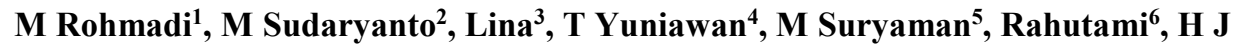 \\ Prayitno $^{7}$, Y Nauscha ${ }^{8}$, M Sufanti $^{9}$, R Susanti ${ }^{10}$ \\ ${ }^{1,2}$ Sebelas Maret University Surakarta, Indonesia \\ ${ }^{3}$ Institut Ilmu Al'quran An Nur Yogyakarta, Indonesia \\ ${ }^{4}$ Semarang State University, Indonesia \\ ${ }^{5}$ Yogyakarta State University, Indonesia \\ ${ }^{6}$ Kanjuruhan Malang University, Indonesia \\ ${ }^{7-9}$ Universitas Muhammadiyah Surakarta, Indonesia \\ ${ }^{10}$ Politeknik Indonusa Surakarta, Indonesia \\ mamad_r76@staff.uns.ac.id
}

\begin{abstract}
Social media is new communication media in Indonesia. The majority of Indonesians use social media to express their ideas as directly or indirectly in various ways of speech. The aims of the research are: (1) how was the strategy of speech which used in humor context on social media to maintain the diversity of multicultural society in Republic of Indonesia (2) how was the implementation of politeness's principle to maintain the diversity of multicultural society in Republic of Indonesia, and (3) how was the function of speech and politeness to develop the diversity of multicultural society in Republic of Indonesia. The method used in the research was qualitative descriptive with pragmatic approach. The data were taken from social media and the technique of analysis used flow technique from the beginning up to the ending and were concluded by deductive technique. The result of the discussion are: (1) strategy of speech used in humor context on social media consisted of: locution speech, illocution speech, and perlocution speech as the media to maintain the diversity of multicultural society in Republic of Indonesia (2) the implementation of politeness's principle in humor context on social media as indirect speech as the media to maintain the diversity of multicultural society in Republic of Indonesia (3) the strategy function and politeness consisted of assuring function, educating, uniting, and entertaining contextually to maintain the diversity of multicultural society in Republic of Indonesia. Therefore, the strategy of decent humor speech in communicating on social media can become a media to maintain the diversity of multicultural society in Republic of Indonesia.
\end{abstract}


Keywords: Social Media, Humor, Speech

\section{INTRODUCTION}

The use of social media can have both negative and positive impacts. Both are considered integrally to indicate which impact has a greater effect. Quantitative explanations are complexly incapable to explain descriptively about the influence or significance of social media usage. The study aims to describe the strategy of speech, implementation of principles of language politeness, and the function of speech strategies on social media as an effort to maintain the unity of republic of Indonesia.

The development of language usage by the society turns to be various. Unfortunately, only a few of them understand that language is not only an explicit analysis statement, but also it has the implicit meaning. [1] thinks that not all of the language not only interpreted by words but also utterance. The listeners can also interprete the language according to the context of the communication. He argued that on some occasions, particular contextual features help the listener to reconstruct the speaker's communicative intention: "To work out that a particular conversational implicature is present, the hearer will reply on the following data: ... the context, linguistic or otherwise, of the utterance. .."

Contextually, data 1 is a product of social humor served in meme which is considered funny for some people. Meme designed in the pattern on advertisement on tokobagus.com whereas, the website specifically selling second-hand goods. The data above is a perlocution. In line [2] states that perlocution is a speech to influence the speaking partner. The way of comedy is performed well without offend anyone so it is acceptable for the society even for its taboo topic [3].

Supported by [1] states that the humor concept above in two different context as contexts effects of linguistic structure and context effects of situation. The way to interpret the context can be seen from two sides; from the speaker or from the reader / listener. There is no limit to interpret the context as it's not homogenous. The definition of the humor also related to personal experience of one who creates or listens it so it can make them laugh [4].

According to the theory of [1], data has wider interpretation, whereas the concept of the speaker (creator) and the listener (reader) was different. There are many factors of the meme such as, (1) disappointment, (2) hatred, even (3) clumsiness or ignorance. Compared with humor according to [5] Humor involves some interactions includes sarcasm and irony in every day's context which is considered funny and also related with gender, power, politeness which is related to pragmatic description of joke. According to [5] data shows banter and sarcasm frequently, it is shown by the plastic and the utterance 'punya presiden tapi tidak berguna' (having president but he's useless). Jokes for particular society can have different meaning with others. [5] deepen the meaning of humor to be more complex. In the end, the meaning in humor utterance is not totally agreed by the society.

Utterance can have various characteristics such as locution which is what one says is a speech to state something. The speech spoken by the speaker related with the action in correlation with saying something for doing something, such as deciding, praying, agreeing, and complaining [2]. Illocution speech is a speech, which is not only spoken to say and to inform 
something, but also to do something. In other words, it is a speech which is spoken by the speaker related with stating something. Illocution speech related with the value in its proportion. For example,

"Saya tidak dapat datang"

“(I can’t come)".

The utterance stated by somebody for his friend who has just held a wedding reception for his daughter. Not only functioned to state something, but also to do something which is apologizing because of his absence in the wedding. Perlocution speech is a speech which is done by saying something, influencing other people to believe in something by insisting or inviting people to do something.

\section{METHOD}

Linguistic research methodology can be interpreted as a working strategy based on particular plans. The method used in the research was descriptive qualitative method, whereas the result of the research contained of quotations and the rules from the analysis results and data observing which were telling, explaining, classifying, analyzing, and interpreting critically. The data analysis was done inductively whereas the analysis come from the facts (data) to theory and not from theory to facts. This was done to avoid data manipulation which caused profile of language usage included the factors which influence the usage to be unrevealed properly and objectively. The focus of critical discourse is on the relation of the discourse toward power, dominance, and social inequality then on reproduce, and maintenance the relations[6].

The data analysis in this research is a content analysis. The analysis emphasizes on the meaning in the humor utterance to describe various language, various context and implicature, various functions, perceptions, and the core of humor textually or contextually. The method of the research was done in three strategic ways, such as (1) data collecting, (2) data analysis, and (3) the result of data analysis. Those three strategic steps following [7]. The humor utterances taken as the samples were the data, which have characteristics according to the writer's (or creator's) will, which represents the population of social media user. The technique of data analysis commonly divided into two, they are quantitative and qualitative.

The result of the research is in a form of qualitative descriptive about the aspects of language in creating humor utterances, various context and implicature which support the humor utterances' creation, various function, perception, and the core of a humor. The result of the research will be shown in two methods, they are (1) formal method, whereas the result will be in words arranging, and (2) informal method, whereas the result will be arranging of signs, codes, tables, and pictures which are necessary as the data analysis support. In understanding the implicature, the speaker (or creator of utterances) should consider many things such as whom he speaks with, where and when the words spoken, and etc.

\section{RESULT and DISCUSSION}

The meaning accepted of a humor becomes the problem of understanding. The different perception creates pre-perception in the particular society to do justification and blame different group. According to critical discourse analysis can be useful for be it research or teaching [8]. 
Dis-perception in the society is a polemic which appears because the difference understanding in the politeness principal which have been agreed.

$$
\begin{aligned}
& \text { P1 : ciuman yuk bang! (Let's kissing, babe!) } \\
& \text { P2 : haram, bukan muhrim. (Haram, we are not married) } \\
& \text { P1 : lipstik wardah bang, hallal kok (the lipstick's brand is Wardah, babe. It's halal) } \\
& \text { P2 : Astagah, Ayo lah. (O my God! Ok let's do it) }
\end{aligned}
$$

Explicitly, data 1 tells about a woman who invites her boyfriend to kiss. But the man refused cause he beliefs that it will be haram. But in the end, the man doesn't refuse cause in the advertisement the brand of the lipstick is announced halal. Implicitly, people who follow Arabian culture but have less knowledge about it will lead him do it in a wrong way. Such as using the wrong way to correct what he has done. It doesn't mean that do something with halal product will lead him to be true if what he has done was a sin. It is supported by [9] that talking about humor is also talking about the surroundings.

The use of humor has correlation with the status, a good humor will show good status while the inappropriate humor is the opposite, When one produces inapproate humor, it means the person cross the boundaries of social value especially when it talks about racism, sexism, etc ([10];[9][11];[12];[13]). The coclusion is, inapproriate humor shows that the person who create it has confidence but lack of competence. Headline news of Lampu Hijau '(1) Mau Puasa Senin-Kamis (Going to have Monday-Thursday fasting), (2) Sahurnya Ngemut 'Burung' ABG (the breakfasting was sucking teenager's genital) (3) Si ABG Lapor Polisi (the teenager reported to the police), (4) $S J$ Ditangkap (SJ was arrested)' (Friday, 17 February 2016)

When $S J$ was about to have Monday-Thursday fasting, he was attempted to rape a teenager and in the end he was arrested. Data shows that there is no correlation of the first statement "Mau Puasa Senin-Kamis (Going to have Monday-Thursday fasting)", with what had done by $S J$, even though [10] states the correlation between the humor and condition, both aspects had no correlation. The religious activity doesn't always change one's behavior to be better. It's always better when the retreat of faith and mental are done together. There is correlation between humor, one's confidence, and competence. When one tells a humor, it shows that the person has good confidence which has correlation in increasing the status. Also mentioned that

\begin{tabular}{|c|c|}
\hline \multicolumn{2}{|c|}{ Dis-content of Sumpah Pemuda } \\
\hline $\begin{array}{c}\text { Kami Putra dan putri Indonesia } \\
\text { bersumpah (we are the Indonesians youth }\end{array}$ & $\begin{array}{l}\text { Kami Putra dan putri Indonesia bersumpah (we are } \\
\text { the Indonesians youth promise) }\end{array}$ \\
\hline promise) & Bangsat lo! Kerbau lo! Ga becus! (You're an \\
\hline Berbangsa satu bangsa Indonesia (One & asshole! Coward! Useless!) \\
\hline nation, one Indonesia) & Presiden cengeng, turun aja lo! (Looser president! \\
\hline Bertanah air satu, tanah air Indonesia & Get out of here!) \\
\hline (One country, one Indonesia) & Drakula! Iblis! Antek Amerika! Tidak prorakyat! \\
\hline $\begin{array}{c}\text { Berbahasa satu, bahasa Indonesia (One } \\
\text { language, Indonesian language) }\end{array}$ & $\begin{array}{l}\text { Tuli dan Buta (Dracula! Evil! America's block! Un- } \\
\text { pro to citizen! Blind and deaf! }\end{array}$ \\
\hline
\end{tabular}
when one fails in making good humor, it means the person has lack of confidence and lack of competence ([10];[9]).

Table 1. The changing content of the Sumpah Pemuda 
The changing content of the Sumpah Pemuda was considered as a criminal because it shows disrespect to history of Indonesia. In data shows that the first lyric contains of swearing words to the reader. The second lyric contains of bullying for the president. The third lyric contains of provocation. The disappointment of the creator is the description of the creator's feelings toward the reader. Actually, criticism is a positive thing that can give correction toward the leader. However, the criticism expected to build a better government's system. Changing the content of Sumpah Pemuda is one of the ways of hate speech to destroy and break the nation's peace. Pragmatic principals omitted in the utterances above were about the language politeness and the meaning quality. The basic problem is the weak understanding of the language politeness. Nowadays, the society is still unable to balance the four language skills as a united synergy [14]. Un-balance understandings of the context of spoken and written utterances, plus the weakness of unbalance productive and receptive skill become the major problem. The ability of the society to understand information is still low, compared the desire to respond and drop an opinion.

There are aslo some cases where humor is failed to make people laugh. Our findings underline the role of humor in not only concerns on how funny it is, but also on how appropriate it is. In general telling something which is not appropriate regarding with soccial norm showed that the humor reach no any competence unless the humor is performed by the expert then the risk can be lower. Humor is as the phenomenon of language, which forms perspective for the language or non-language society. That humor contains of negative content an unexpected meaning).

Even though the presented utterances based on the language context, but it was out of the first topic. The use of language variation by changing the meaning of a context is one of the humor's principals. That perspective appears in line with the mindset and the critical thinking of humor's reader. The basic chriteria of the aim of a humor according to [5] Humor must contain of the element of performing the humor, receiving the humor and respond the humor or jokes. It has been stated in the beginning that humor can build strenghth, solidarity, and politeness.

\section{CONCLUSION}

In the context of humor, the language community receives instant understanding. This is also due to the understanding of the principle of politeness or politeness in the community in the realm of language and non-language that there are still differences in perception. In fact, the conventional media communication concept approach still uses or one-way communication and focuses on the transmission of messages to be delivered to the user. While in the new media be it social media or networking use the concept of two-way communication theory and can give each other directly or indirectly feedback. Based on the population of data collected, most of the humor discourse contains per-locution speech action. A good sense of humor can certainly be linked to a pragmatic principle that fits the context. In the end, the concept of the basic boundaries can be used to strengthen inter-community relationships in one class. In a state, society can be restricted and given leeway in understanding tolerance on the basis of understanding the context of humor in a pragmatic perspective.

Discourse or utterance of humor that developed in the community contains several strategies in general, speech strategy used in the context of humor in social media consists of: speech, illocution, and per-locution as media to maintain diversity in multicultural society in 
Republic of Indonesia. [15] defines discourse analysis into (a) related with boundaries of sentences (b) related with language and society (c) related with interactiv and dialogic of daily communication. Discourse of humor that evolved from various social media is implemented through the principles of language politeness or politeness in the context of humor in social media consists of indirect speech acts are acts of speech that serves to encourage listeners to do something as a medium to maintain diversity of multicultural society in Republic of Indonesia, and the function of strategy speech and courtesy consists of the function of convincing, motivating, educating, uniting, and entertaining contextually to build diversity of multicultural society in Republic of Indonesia.

\section{REFERENCES}

[1] Z. Xu, "Contextual dimensions in interactional humour: How humour is practiced in selected American and Chinese situation comedies," J. Pragmat., vol. 60, pp. 24-35, Jan. 2014.

[2] M. Rohmadi, "Strategi Penciptaan Humor dengan Pemanfaatan Aspek-aspek Kebahasaan," J. Hum., vol. 22, no. 3, pp. 285-298, 2010.

[3] Oskar Folk, Representations of ethnicity in stand-up comedy: A study of the comedy of Dave Chappelle University of Gothemburg Department of languages and literature. Gothehemburg: Department of Language and Literature, 2010.

[4] D. Rahmanadji, "Sejarah, teori, jenis, dan fungsi humor," J. Bhs. Dan Seni, vol. 35, no. 2, pp. 213-221, 2007.

[5] N. R. Norrick, "Humor in Interaction," Lang. Linguist. Compass, vol. 4, no. 4, pp. 232 244, Apr. 2010.

[6] T. A. van Dijk, "Principles of Critical Discourse Analysis," Discourse Soc., vol. 4, no. 2, pp. 249-283, Apr. 1993.

[7] J. C. Richards, "Learning a second language," System, vol. 11, no. 1, pp. 89-91, Jan. 1983.

[8] T. van Leeuwen, "Critical Discourse Analysis," in Encyclopedia of Language \& Linguistics, Elsevier, 2006, pp. 290-294.

[9] C. Anderson and G. J. Kilduff, "The Pursuit of Status in Social Groups," Curr. Dir. Psychol. Sci., vol. 18, no. 5, pp. 295-298, Oct. 2009.

[10] C. Anderson, S. Brion, D. A. Moore, and J. A. Kennedy, "A status-enhancement account of overconfidence.," J. Pers. Soc. Psychol., vol. 103, no. 4, pp. 718-735, 2012.

[11] Y.-R. Chen, R. S. Peterson, D. J. Phillips, J. M. Podolny, and C. L. Ridgeway, "Introduction to the Special Issue: Bringing Status to the Table-Attaining, Maintaining, and Experiencing Status in Organizations and Markets," Organ. Sci., vol. 23, no. 2, pp. 299-307, Apr. 2012.

[12] J. A. Kennedy, C. Anderson, and D. A. Moore, "When overconfidence is revealed to others: Testing the status-enhancement theory of overconfidence," Organ. Behav. Hum. Decis. Process., vol. 122, no. 2, pp. 266-279, Nov. 2013.

[13] C. Ridgeway, "The Social Construction of Status Value: Gender and Other Nominal Characteristics," Soc. Forces, vol. 70, no. 2, pp. 367-386, Dec. 1991.

[14] S. Memet, Sumarwati, and E. Suryanto, "Register Anak Jalanan Kota Surakarta," BASASTRA J. Penelit. Bahasa, Sastra Indones. dan Pengajarannya, vol. I, no. 3, pp. 514-528, 2014.

[15] L. Cuinat, N. Nasr, J. M. Kamsu, F. Tanchoux, F. Bonneville, and V. Larrue, "Meningeal Disease Masquerading as Transient Ischemic Attack," J. Stroke 
Cerebrovasc. Dis., vol. 23, no. 6, pp. 1738-1743, Jul. 2014. 